\title{
Circularity in the Management of Municipal Solid Waste - A Systematic Review
}

\author{
Dilip KHATIWADA ${ }^{1 *}$, Farzin GOLZAR ${ }^{2}$, Brijesh MAINALI ${ }^{3}$, \\ Aarthi Aishwarya DEVENDRAN ${ }^{4}$ \\ 1,2Division of Energy Systems, Department of Energy Technology, KTH Royal Institute of Technology, \\ 10044 Stockholm, Sweden \\ ${ }^{3,4}$ Department of Built Environment and Energy Technology, Linnaeus University, 35195 Växjö, Sweden
}

\begin{abstract}
Municipal solid waste (MSW) management has emerged as one of the major environmental challenges globally. The consequences of inappropriate waste management are manifold and the trend would continue if immediate interventions are not taken for its reversion amid rapid urbanization and current consumption patterns of individuals. The concept of circular economy (CE) can contribute to a paradigm shift in the transformation of the traditional linear approach that does not favour reuse, recycle, recovery concept. Modern and proven waste management practices with collection systems, recycling facilities, sanitary landfills, and waste-to-energy (WtE) and nutrient recovery offer opportunities to improve urban environment through the valorization of waste and by-products in a CE. This study scrutinizes the existing literature on the assessment of circularity and helps to develop a unified circularity framework in the management of MSW in cities. Key aspects such as tools for measuring circularity, nexus and trade-offs, and conditions in promoting $C E$ are discussed. Finally, this paper elucidates the need for circularity, including enablers and inhibitors for promoting circularity in the management of MSW with a case study in the city of Curitiba, Brazil.
\end{abstract}

Keywords - Circular Economy (CE); Municipal Solid Waste (MSW); nexus and trade-offs; resource recovery; tools for measurement

\begin{tabular}{|ll|}
\hline \multicolumn{2}{l|}{ Nomenclature } \\
AD & Anaerobic Digestion \\
CHP & Combined Heat and Power \\
EoL & End of Life \\
LCA & Life Cycle Assessment \\
LFG & Landfill Gas \\
MSW & Municipal Solid Waste \\
WtE & Waste to Energy \\
\hline
\end{tabular}

\section{INTRODUCTION}

Municipal solid waste (MSW) management has emerged as one of the major environmental

${ }^{*}$ Corresponding author.

E-mail address: dilip.khatiwada@energy.kth.se

C2021 Dilip Khatiwada, Farzin Golzar, Brijesh Mainali, Aarthi Aishwarya Devendran.

This is an open access article licensed under the Creative Commons Attribution License (http://creativecommons.org/

licenses/by/4.0). 
challenges globally. The consequences of inappropriate waste management are manifold, including environmental hazards such as air pollution and water contamination, negative impacts on public health, and greenhouse gas (GHG) emissions [1]-[3]. The world generates 2 billion tonnes of MSW annually and around $33 \%$ of that is not managed in environmentally benign way [4]. As the urbanization and population growth continue the global municipal waste is expected to rise, reaching 3.4 billion tonnes by 2050 [4]. Current trends of consumption patterns would pose threats to the urban environment and the maintenance of ecosystem services.

The management of MSW involves several steps, viz. waste collection, sorting/segregation, transportation to treatment facilities, selection of suitable technologies, resource recovery, and their sustainability aspects such as environmental pollution, income, and job creation. Traditionally, MSW is directly sent to open landfills or dump sites without resource recovery in developing countries [5], whereas wastes are burnt in incineration plants to produce electricity in developed countries [6]. Thus, it has used a linear approach that does not favor reuse, recycle, recovery concept without returning materials to the biosphere. Modern and proven waste management practices with collection systems, recycling facilities, sanitary landfills, and waste-to-energy (WtE) recovery offer opportunities to improve local urban environment, while also adding value to the waste and by-products [2], [7].

Recently, the concept of circular economy (CE) appeared as a paradigm shift in the management of MSW [8]. The CE promotes minimizing waste, reuse and recycling of waste, adding the value of resources, materials, and products so that it remains for a long time. There are several waste management options, starting from landfills, incineration, composting to anaerobic digestion (AD) (Fig. 1).

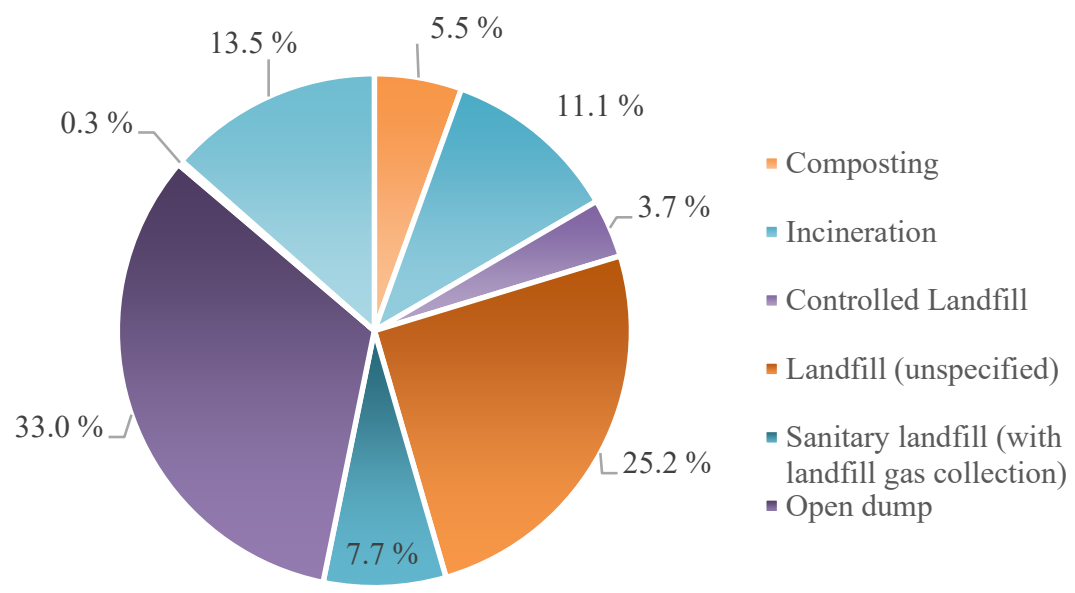

Fig. 1. Share of the global treatment and disposal of waste in 2017 [4].

Disposal of unsorted MSW in landfills is still a prevailing practice in developing countries [3]. In the landfills, different kinds of solid waste are anaerobically digested generating Landfill Gas (LFG) and leachate. Composting is a biological treatment process where organic waste is transformed into a nutrient-rich material in the absence of oxygen, also known as compost [9]. AD is a biological conversion process in which organic fraction of the MSW is decomposed by microorganisms to produce biogas (a blend of methane and carbon dioxide) 
and slurry (nutrient-rich digestate) [10]. AD is considered a mature technology and has been widely implemented in different scales globally. In the incineration, the waste is combusted at temperatures to produce heat and electricity at CHP plants [6]. Waste is considered as the main feedstock in advanced bio-refineries that is analogous to traditional oil-refineries where we produce multiple bio-products. The major portion of MSW is derived from biological origin and biomass plays a key role in the CE [11], [12]. Waste biorefineries act as enablers for promoting $\mathrm{CE}$ in developing countries [13].

Several studies have reviewed CE perspective in solid waste management [14]. Waste prevention, energy recovery or recycling are being promoted in the light of circular economy [15]. The concept of sustainability includes environmental, economic, and social dimensions. Life Cycle Assessment (LCA) has been used to find the environmental impacts of MSW options [16], [17]. Lately, social lifecycle assessment (sLCA) [18] and lifecycle costing (LCC) [19] have included the other two domains. Material flow analysis (MFA) [20] has also been used to evaluate the performance of solid waste management. Multi-criteria assessment is used to analyse waste treatment options for food and biodegradable waste Management in Japan [21] and WtE technologies in Oman [22]. Different solid waste treatment scenarios are analysed in rapidly urbanizing cities in developing countries[23]. Abdallah et al. have performed a systematic research review on the role of Artificial Intelligence (AI) applications in solid waste management [24]. Kalmykova et al. presented implementation tools for circular economy (CE) [25]. Gallego-Schmid et al. reviewed the links between CE and climate change mitigation in the built environment [26]. The major portion of MSW is derived from biological origin and biomass plays an important role in the $\mathrm{CE}$ [11], [12]. The role of MSW management and WtE is considered as a key in the implementation of a CE and bio-based economy [5], [27]. In spite of tools and techniques in the assessment of MSW management and introduction of the concept of CE in the waste sector, there is limited literature on how to measure the circularity in a holistic and integrated way. This study aims to systematically review the existing literature on the assessment of circularity and propose a unified framework for assessing the CE in the management of MSW in cities.

\section{SeARCH FOR CiRcularity In THE MSW Management SeCtor}

A systematic review of literature (SLR) is used to identify, evaluate, and interpret studies in the selected area of interest [28]. SLR approach is applied to assess the circularity in agrifood sector and organic solid waste management [14], [29].

In this study, authors used the Web of Science 'WoS' literature search to find the related articles. In order to examine the tools and indicators used for measuring circularity in the waste management we used the following strings in the WoS: TI = ('waste management' AND 'circular economy') AND AB= (('citi*' OR 'waste*' OR 'municipal*') AND 'method' OR 'framework' OR 'metric*' OR 'Indicator*' OR 'Tool*' OR 'case*').

The main objective of this study is to identify and evaluate the studies that are used to measure the performance of MSW management in cities. The key performance indicators and tools are mapped in the context of CE. We also applied the 'Snowballing' technique for identifying important articles relevant to answer the specific research questions outlined below:

- What are the tools and methods to measure the sustainability of the MSW management? How is the performance of the selected tools and methods?

- What are the factors that influence the performance of waste management in the 
circular concept?

- How can conditions be established for promoting circular economy in waste management?

- What are the trade-offs and synergies in the integrated assessment of municipal waste management?

Finally, we applied the circularity measurement framework for urban waste management: what are the conditions (enablers and inhibitors) and how circularity can be promoted in the city of Curitiba, Brazil (Section 4)?

\section{Evaluating Circularity and Nexus in the Management of the MSW IN CITIES}

First, we present tools and indicators used for measuring circularity in the MSW sector. Conditions and trade-offs in achieving the innovative circular solutions and sustainable development are described. The need for an integrated assessment method is also discussed.

\subsection{Tools for measuring circularity in the MSW sector}

A wide variety of tools, methods, models, and frameworks have been implemented to investigate different aspects of the MSW sector's circularity. When it comes to addressing the goal of a sustainable consumption and production, all action plans need to be managed towards a minimal environmental impact and a maximal economic impact. This has necessitated the need for the development of optimization tools for environmental and technoeconomic assessments. Hrabec et al. [30] proposed a robust two-stage integer non-linear program to develop the near-optimal waste allocation for its appropriate processing as well as waste transportation plan at an operational level. Rathor et al. [31] formulated a mixedinteger non-linear program (MINLP) model to examine the use of collected organic MSW for producing biogas and then its application as a fuel in a thermal power plant to decrease the burden on coal mines. Loizia et al. [32] focused on the fact that how can we optimize and improve the production of biogas from upflow anaerobic sludge blanket reactor using natural minerals (clinoptilolite). Molina-Sánchez et al. [33] presented optimization models for wastewater from paper mills which are related to the sustainability and circular economy model. The concept of circular economy was implemented in the paper mill's wastewater treatment, with the objective of recovering the material resources contained in this type of effluent. Fetanat et al. [34] proposed a hybrid method to aggregate the sustainability dimensions of circular economy strategies. They developed a fuzzy three-phase group multiple-criteria decision-making approach integrating fuzzy analytic network process, fuzzy decision-making trail and evaluation laboratory and fuzzy multi-objective optimization on the basis of ration analysis.

In addition to optimization tools, there is a need for developing assessment tools to analyze and predict the impacts of various action plans on the circularity of MSW management. Sadeleer et al. [15] integrated a material flow analysis (MFA) considering the downstream system with published LCA results for the upstream system to investigate the environmental impacts of two waste management systems for household organic food waste, namely recycling by anaerobic digestion (AD) and incineration. To analyze the impact of changes related to waste management system structure, Tomic et al. [35] was adjusted and used a time-dependent LCA based waste, material, and energy flow tracking framework to calculate material and energy production, which can be monetized. Berechet et al. [36] utilized LCA approach in a case study in Timisoara, Romaniato to understand the role of waste as a 
secondary resource and recovering it can decrease the consumption of non-renewable primary resources and can reduce the $\mathrm{CO}_{2}$ emissions.

The quantity and the category of municipal waste generated vary according to the anthropogenic activities and the level of technological development of a city [4]. Multicriteria evaluation (MCE) method in a Geographical Information System (GIS) environment is used to evaluate the sustainability of potential landfill sites [37], [38]. The potential advantage of using spatial and multi-criteria analysis approach can reduce the time and cost of the landfill site selection [38]. Several studies have been carried out on landfill site selection for municipal solid waste through GIS based MCE approaches [37], [39], [40]. Obviously, optimized transportation of wastes by selecting the shortest route can save time and cost in handling the solid waste. Additionally, the use of spatial modeling tools and GIS for collection and transportation optimization can provide economic and environmental gains by reducing travel time, distance, and fuel consumption [41].

Alkaradaghi et al. [42] proposed a GIS based MCE tool for landfill site selection in Sulaimaniyah, Iraq. In Srem region of North Serbia, the traditional method of site selection for landfills was replaced by the implementation of GIS based Analytical Hierarchy Process (AHP) technique [43]. Though the geo-spatial tools have major contributions in the effective management of MSW of cities, the most common inhibtors in the implementation of MSW management of cities is the lack of digital databases. In most of the cities of developing countries, the database related to the solid waste generated/day, categories of waste generated at source level and mostly the transportation network data of vehicles carrying the waste are not available. It could be because of the lack of awareness among the citizens regarding the solid waste management and also due to the lack of fundings for the governing authorities to maintain such digital databases.

Nevertheless, in addition to optimization, assessment models, and geospatial tools, the institutional relations assessment tools should be enhanced in facilitating the circularity in the MSW sector. To study the stakeholder collaboration in CE waste management of cities, Palafox-Alcantar et al. [44] proposed a methodology which consists of six steps: i) defining stakeholders and ambitions; (2) formulating future scenarios for MSW Management; (3) survey stakeholders to classify the evaluation indicators; (4) determine the weights for the scenarios criteria; (5) show the preference order of the scenarios; and (6) analyse the preferences to reveal the cooperation and competitive opportunities. Sharma et al. [45] evaluated and established a cause-effect relationship among the enablers of e-waste management (e-WM) using a DEMATEL approach. The interrelationship among the enablers and the intensity of influencing each other are investigated by DEMATEL method. The relationship is quantified on the scale of 0 to 4 where 0 indicates that variable ' $x$ ' does not have any influence on ' $y$ ' and 4 indicates that ' $x$ ' influences ' $y$ ' significantly. This method is used to reveal the interdependency of one variable on other.

Model and tools for measuring circularity can be divided into four categories, viz. i) optimization tools and models; ii) techno-economic and environmental assessment methods; iii) geospatial tools for measuring the circularity; and iv) institutional relations assessment models. Some of the most potential expert tools that can be implemented for evaluating CE in municipal waste management are summarized in Table 1. As presented, there are a wide variety of tools for different domains or purposes. For instance, LCA is a powerful tool for comparing various technological or strategical alternatives. Mixed-integer programming helps to determine the most profitable pathway toward a CE. However, considering the multidimensional aspects of waste management in urban areas, a combination of different tools should be used to cover all crucial parts of circularity analysis. 


\subsection{Identification of key factors in promoting circular economy}

The influential factors affecting the circularity could be different considering the scales of waste recovery. For example, the parameters determining the circularity of the waste management in a production company are different with a municipal waste management in a city [33], [46]. Molina-Sánchez [33] concluded that the indicators of CE implemented to wastewater from a paper mill are the removal performance of color, total suspended solids (TSS), biochemical oxygen demand on the fifth day (BOD5), and chemical oxygen demand (COD). Symeonides et al. [46] investigated tire waste management system in Cyprus in the CE strategy framework and it is concluded that bureaucracy, policy/regulations and logistics are the significant caveats for CE. Salguero-Puerta [47] introduced the concept of CE to evaluate the improvement obtained due to reduction, reuse, and recycling of waste generated on the campus of the University of Lome (Togo). It depicts that even in small-scale cases like tire company, paper mill production and university campus the impactful factors are totally different.

TABLE 1. TOOLS AND METHOdS FOR MEASURING CIRCULARITY IN THE MSW SECTOR

\begin{tabular}{|c|c|c|c|}
\hline Category & Tool & Application & Reference \\
\hline \multirow{4}{*}{ 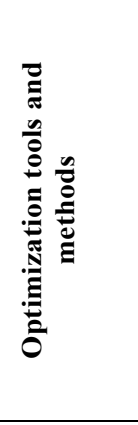 } & $\begin{array}{l}\text { Two-stage integer } \\
\text { non-linear program }\end{array}$ & $\begin{array}{l}\text { Development of the near-optimal waste } \\
\text { allocation }\end{array}$ & $\begin{array}{l}\text { Hrabec et al. } \\
{[30]}\end{array}$ \\
\hline & $\begin{array}{l}\text { mixed-integer non- } \\
\text { linear program } \\
\text { (MINLP) model }\end{array}$ & $\begin{array}{l}\text { Examining the use of collected organic MSW } \\
\text { for producing biogas }\end{array}$ & $\begin{array}{l}\text { Rathor et al. } \\
\text { [31] }\end{array}$ \\
\hline & $\begin{array}{l}\text { Multivariable } \\
\text { statistical analysis } \\
\text { applying the software } \\
\text { Canoco }\end{array}$ & $\begin{array}{l}\text { Recovering the material resources contained in } \\
\text { paper mill's effluent }\end{array}$ & $\begin{array}{l}\text { Molina- } \\
\text { Sánchez et al. } \\
\text { [33] }\end{array}$ \\
\hline & $\begin{array}{l}\text { fuzzy three-phase } \\
\text { group multiple- } \\
\text { criteria decision- } \\
\text { making approach }\end{array}$ & $\begin{array}{l}\text { Aggregating the sustainability dimensions of } \\
\text { circular economy strategies }\end{array}$ & $\begin{array}{l}\text { Fetanat et al. } \\
\text { [34] }\end{array}$ \\
\hline \multirow{4}{*}{ 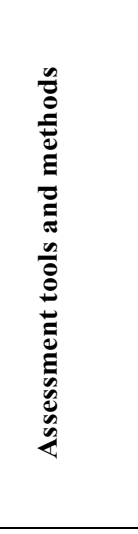 } & $\begin{array}{l}\text { Life Cycle } \\
\text { Assessment (LCA) }\end{array}$ & $\begin{array}{l}\text { Understanding the role of waste as a secondary } \\
\text { resource to decrease the consumption of non- } \\
\text { renewable primary resources, and also reduce } \\
\text { the } \mathrm{CO}_{2} \text { emissions } \\
\text { Assessing the environmental performance of } \\
\text { different waste management alternatives }\end{array}$ & $\begin{array}{l}\text { Berechet et al. } \\
{[36]} \\
\text { Laso et al. }[50]\end{array}$ \\
\hline & $\begin{array}{l}\text { Integrated a material } \\
\text { flow analysis (MFA) } \\
\text { with life cycle } \\
\text { analysis (LCA) }\end{array}$ & $\begin{array}{l}\text { Investigating the environmental impacts of } \\
\text { anaerobic digestion (AD) and incineration }\end{array}$ & $\begin{array}{l}\text { Sadeleer et al. } \\
\text { [15] }\end{array}$ \\
\hline & $\begin{array}{l}\text { Time-dependent and } \\
\text { monetized Life Cycle } \\
\text { Assessment }\end{array}$ & $\begin{array}{l}\text { Analyzing the impact of changes related to } \\
\text { waste management system structure }\end{array}$ & $\begin{array}{l}\text { Tomic et al. } \\
\text { [35] }\end{array}$ \\
\hline & $\begin{array}{l}\text { Waste hierarchy } \\
\text { index (WHI) }\end{array}$ & $\begin{array}{l}\text { Evaluating the waste hierarchy within a circular } \\
\text { economy context, implemented to municipal } \\
\text { solid waste }\end{array}$ & Pires et al. [51] \\
\hline \multirow{2}{*}{ 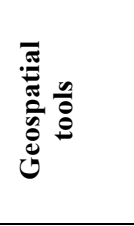 } & $\begin{array}{l}\text { Geographical } \\
\text { Information System } \\
\text { (GIS) }\end{array}$ & $\begin{array}{l}\text { Providing time and cost-effective solutions by a } \\
\text { digital database of the municipal solid waste } \\
\text { system of a city for a long-term monitoring and } \\
\text { analysis }\end{array}$ & Ersoy [38] \\
\hline & $\begin{array}{l}\text { GIS-based multi- } \\
\text { criteria evaluation } \\
\text { (MCE) approaches }\end{array}$ & $\begin{array}{l}\text { Identifying appropriate sites for landfills } \\
\text { satisfying the criteria }\end{array}$ & $\begin{array}{l}\text { Alkaradaghi, et } \\
\text { al. [42] }\end{array}$ \\
\hline
\end{tabular}


$2021 / 25$

\begin{tabular}{|l|l|l|l|}
\hline & $\begin{array}{l}\text { GIS-based Analytical } \\
\text { Hierarchy Process } \\
\text { (AHP) technique }\end{array}$ & $\begin{array}{l}\text { Feasibility study with site investigation public } \\
\text { perception survey, and consideration of } \\
\text { ownership and land price }\end{array}$ & $\begin{array}{l}\text { Zelenović } \\
\text { Vasiljević [43] }\end{array}$ \\
\hline \multirow{3}{*}{$\begin{array}{l}\text { DEMATEL approach } \\
\text { Evaluating and establishing a cause-effect } \\
\text { relationship among the enablers of e-waste } \\
\text { management (e-WM) }\end{array}$} & $\begin{array}{l}\text { Sharma } \text { et al. } \\
\text { [45] }\end{array}$ & $\begin{array}{l}\text { Mahpour [52] } \\
\text { framework }\end{array}$ & $\begin{array}{l}\text { Palafox- } \\
\text { Alcantar } \text { et al. } \\
\text { [53] }\end{array}$ \\
\cline { 2 - 5 } & $\begin{array}{l}\text { Fuzzy TOPSIS } \\
\text { method }\end{array}$ & $\begin{array}{l}\text { Analyzing stakeholders' interactions with } \\
\text { multiple objectives and perspectives }\end{array}$ & $\begin{array}{l}\text { Bartolacci } \text { et al. } \\
\text { [54] }\end{array}$ \\
\cline { 2 - 5 } & Game theory & $\begin{array}{l}\text { Verifying if and how separate waste collection } \\
\text { rates impact production costs }\end{array}$ & $\begin{array}{l}\text { Parajuly } \text { et al. } \\
\text { [55] }\end{array}$ \\
\cline { 2 - 5 } & $\begin{array}{l}\text { Covariance } \\
\text { ANCOVA) } \\
\text { statistical method }\end{array}$ & $\begin{array}{l}\text { Improving the current EoL practices and } \\
\text { support designers in making EoL thinking } \\
\text { operational during the product design stage }\end{array}$ & Product family \\
philosophy & &
\end{tabular}

In large-scale cases like a municipality, Luttenberger [48] mentioned the most crucial CE indicators considering municipal waste as generation of municipal waste per capita, generation of waste excluding major mineral wastes per GDP unit, generation of waste excluding major mineral wastes per domestic material consumption, municipal waste recycling rate, overall packaging recycling rate, plastic packaging recycling rate, biowaste recycling, the recovery rate of construction and demolition waste, the contribution of recycled materials to raw materials demand, private investment, jobs and gross added related to circular economy sectors, gross investment in tangible goods, persons employed, and the number of patents related to recycling and secondary raw materials. Tsai et al. [49] recognized the top 5 indicators for enhancement and provided an innovative regional comparison for municipal solid waste management in a circular economy as incineration, life cycle assessment, plastic waste, sorting solid waste, and sustainability.

Some of the key parameters affecting the CE are summarized in Table 2. It is concluded that considering scale, the key factors widely vary depending on the problems being addressed, the audience, or the lens through which the author views the world. However, the EC's core elements relate to direct circular handling of material and energy flows - for example, closing loops, extending product life cycles, and increasing usage intensity. In addition, ensuring renewable, reusable, non-toxic resources are utilized as materials and energy in an efficient way.

TABle 2. Key FaCtors AfFecting the CiRCUlarity in MSW Management

\begin{tabular}{|c|c|c|c|}
\hline Scale & Indicators & Application & Reference \\
\hline \multirow{3}{*}{ 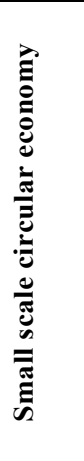 } & $\begin{array}{l}\text { Reduction of waste } \\
\text { Reuse of waste } \\
\text { Recycling of waste }\end{array}$ & $\begin{array}{l}\text { A campus of the } \\
\text { University of Lome } \\
\text { (Togo). }\end{array}$ & $\begin{array}{l}\text { Salguero- } \\
\text { Puerta [47] }\end{array}$ \\
\hline & $\begin{array}{l}\text { The removal performance of color } \\
\text { Total suspended solids (TSS) } \\
\text { Biochemical oxygen demand (BOD5) } \\
\text { Chemical oxygen demand (COD) }\end{array}$ & $\begin{array}{l}\text { Wastewater treatment } \\
\text { from a paper mill } \\
\text { company }\end{array}$ & $\begin{array}{l}\text { Molina- } \\
\text { Sánchez [33] }\end{array}$ \\
\hline & $\begin{array}{l}\text { Legislation of specific goal for the recovery } \\
\text { indication of tires } \\
\text { Centralized logistic system to control the existing } \\
\text { management systems } \\
\text { Technical and economic data guaranteeing the } \\
\text { financial viability of a centralized treatment unit }\end{array}$ & $\begin{array}{l}\text { Tire waste management } \\
\text { system }\end{array}$ & $\begin{array}{l}\text { Symeonides } \\
\text { et al. [46] }\end{array}$ \\
\hline
\end{tabular}


$2021 / 25$

\begin{tabular}{|c|c|c|c|}
\hline \multirow{6}{*}{ 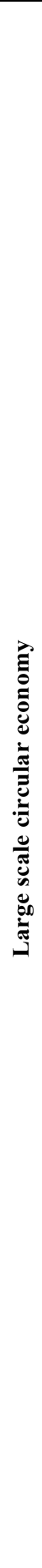 } & $\begin{array}{l}\text { Generation of municipal waste per capita } \\
\text { Generation of waste excluding major mineral wastes } \\
\text { per GDP unit } \\
\text { Generation of waste excluding major mineral wastes } \\
\text { per domestic material consumption } \\
\text { Recycling rate of municipal waste } \\
\text { Recycling rate of overall packaging } \\
\text { Recycling rate of plastic packaging } \\
\text { Recycling of biowaste } \\
\text { Recovery rate of construction and demolition waste } \\
\text { Contribution of recycled materials to raw materials } \\
\text { demand } \\
\text { Private investment } \\
\text { Jobs and gross added related to circular economy } \\
\text { sectors } \\
\text { Gross investment in tangible goods } \\
\text { Persons employed } \\
\text { Number of patents related to recycling and } \\
\text { secondary raw materials }\end{array}$ & $\begin{array}{l}\text { Municipal waste } \\
\text { management in a } \\
\text { country level }\end{array}$ & $\begin{array}{l}\text { Luttenberger } \\
{[48]}\end{array}$ \\
\hline & $\begin{array}{l}\text { Preparing for reuse } \\
\text { Up-cycling } \\
\text { Rerecycling } \\
\text { Composting and anaerobic digestion from source } \\
\text { Separation } \\
\text { Down-cycling } \\
\text { Biological treatment of mixed/residual MSW } \\
\text { Incineration with energy recovery } \\
\text { Incineration without energy recovery } \\
\text { Landfill }\end{array}$ & $\begin{array}{l}\text { Municipal waste } \\
\text { management in a } \\
\text { country level }\end{array}$ & $\begin{array}{l}\text { Pires et al. } \\
\text { [51] }\end{array}$ \\
\hline & $\begin{array}{l}\text { Incineration } \\
\text { Life cycle assessment } \\
\text { Plastic waste } \\
\text { Sorting solid waste } \\
\text { sustainability }\end{array}$ & $\begin{array}{l}\text { Regional comparison for } \\
\text { municipal solid waste } \\
\text { management }\end{array}$ & $\begin{array}{l}\text { Tsai et al. } \\
\text { [49] }\end{array}$ \\
\hline & $\begin{array}{l}\text { Recycling rates (RRs) } \\
\text { Closed-loop collection rate (CCR) } \\
\text { Open-loop collection rate (OCR) }\end{array}$ & $\begin{array}{l}\text { Recycling of paper, } \\
\text { cardboard, aluminum, } \\
\text { tinplate, glass, and } \\
\text { polyethylene } \\
\text { terephthalate (PET) } \\
\text { from MSW in } \\
\text { Switzerland }\end{array}$ & $\begin{array}{l}\text { Haupt et al. } \\
\text { [56] }\end{array}$ \\
\hline & $\begin{array}{l}\text { Appliacation of the material recovered from landfill } \\
\text { in a waste-to-energy process } \\
\text { Reuse of the re-gained land in case of landfill } \\
\text { mining } \\
\text { Reuse of the capped landfill for energy crop } \\
\text { cultivation } \\
\text { Gasification in a biogas plant in case of a remaining } \\
\text { landfill }\end{array}$ & $\begin{array}{l}\text { Reuse options in } \\
\text { developing countries }\end{array}$ & $\begin{array}{l}\text { Schneider et } \\
\text { al. [57] }\end{array}$ \\
\hline & $\begin{array}{l}\text { Functioning cost } \\
\text { Transportation cost } \\
\text { Hiring cost } \\
\text { Environmental cost } \\
\text { Social cost } \\
\text { Penalty cost }\end{array}$ & $\begin{array}{l}\text { Total cost of the } \\
\text { economic, } \\
\text { environmental, and } \\
\text { social feasibility of } \\
\text { municipal solid waste } \\
\text { (MSW) management }\end{array}$ & $\begin{array}{l}\text { Rathor et al. } \\
\text { [31] }\end{array}$ \\
\hline
\end{tabular}


Profitable transitioning to a CE city demands understanding the key parameters affecting $\mathrm{CE}$ and a comprehensive approach that includes bringing together various partners and stakeholders who may not have similar aims and objectives [44]. A major way to successful implementation is accepting the policy and the public's partnership [58]. Therefore, the policy process should be transparent, and public participation needs to be organised and supported by information, consultation, and educational activities [58]. Ribić et al. [59] showed that to move towards the implementation of the CE approach, not only will they have to invest in new infrastructure to reach the aims, but also will have to improve public awareness in diverting the waste at the household level. It is suitable for stakeholders to work together to create jointly-held perceptions of value, yet collaboration in such an environment is likely to prove difficult in practice [44]. Smol et al. [60] illustrated an inventory of the recommended actions, which support CE transformation in the MSW management. These actions have been categorized into six pillars of circularity, presented in the ReSOLVE framework: Regenerate, Share, Optimize, Loop, Virtualize, and Exchange. In each of the presented areas, proposed tasks and actions were recognized that should be considered by governments and citizens, such as landfill remediation, application of selected municipal waste fractions for economic purposes, sharing products with co-users, waste recovery, remanufacturing products, virtual solutions in everyday life to decrease the amount of generated waste, or replacement of household appliances by items with a higher energy class.

The application of information and communication technology and the internet of things offers a new generation approach to effectively and efficiently improve the global waste management system in developed countries [61]. Future research is to improve the validity and reliability of the instruments for data gathering.

Overall, implementing a circular model associates several actors, challenges, and obstacles. The analyzed sectors are established in different sectors, and the results show that industrial symbiosis, collaboration, and technology play a crucial role in promoting a circular economy. Developing an infrastructure for logistics is essential for the providing of a circular business model. Analyzing the enablers is vital in promoting a circular economy allowing sustainability to be considered for business purpose and processes

\subsection{Towards nexus and integrated approach}

The management of municipal wastes in cities interacts with several systems, viz. water, energy, food, and climate, land use at different levels, intensity, and direction (positive or negative). The underlying linkages or relation is known as 'nexus'. The nexus is the intricate balance between the systems. The nexus is the relation between climate change, water, land use, food, agriculture, and energy [62]-[64]. Many studies have been conducted to find the correlation between scarce resources such as water, energy and land, and the production of food. Howells et al. [62] postulated how integrated assessment of land, energy, water is important for efficient utilization of resources and climate change mitigation. The nexus presents linkages, interconnectivity, and interdependencies of energy, water, and food and waste management systems [63]. Lehmann has introduced the urban nexus framework for a circular economy in cities, linking energy, water, food and waste (EWFW) [64]. A review by Meng et al. [65] showed that there is an urgency of a coherence framework for urban energy-water-carbon nexus.

Wastewater from domestic houses pollutes the water bodies and local environment if not managed and treated appropriately. Collection and treatment of wastewater not only recover clean water and nutrient, but also energy in treatment plants and thus promoting resource and energy efficiency. Mo and Zhang [66] have reviewed energy-nutrients-water nexus 
considering the integrated resource recovery in municipal wastewater treatment plants.

$\mathrm{Xu}$ et al. [67] investigated how integrated water-food-energy nexus in terms of energy recovery and nutrient consumption can be created as one of the new waste management strategies. Artioli et al. [68] identified potential trade-offs and complementarities between interdependent water, energy and food systems for urban governance. The nexus concept is applied in urban agriculture (UA), also considering social dimesions and people's behavior in terms of resource utilization in addition to food, energy, and water [69]. LCA and MFA are the keys for establishing connection with the key factors. Political and institutional dimensions of the nexus debate would reflect the role of urban government in the management of waste management challenges globally. Fouladi et al. [70] have developed an energywater-food (WEF) framework to capture the trade-offs and synergies between sustainability dimensions within an industrial park. The trade-offs between the costs and environmental emissions while synergies between the use of biomass for energy production and climate change mitigation are identified. LCA tool is used to assess system alternatives towards Water-Energy-Waste nexus in the cities [71]. The systems integration would drastically reduce environmental impacts, improve resource efficiency while promoting urban sustainability. Caputo et al. [69] proposed a methodology for measuring resource efficiency, food production and health benefits when it comes to the deployment of urban agriculture (UA) in the nexus approach at a garden scale to the city scale. CE shall be promoted in the waste management sector via resource recycling, reuse, energy generation, resource efficiency.

The need for integrated holistic approaches covering all sysems are urgently required [63][65], [69]. The nexus should be evaluated in both positive and negative aspects, i.e. synergetic linkages and trade-offs linkages in the maintenance of urban ecosystems. There is a great opportunity to include the interactions between MSW management options with energy, land use, climate change. Integrated MSW options would be able to balance potential trade-offs while delivering resource, nutrients, materials which will be later translated into social welfare and sustainable development.

\subsection{Linking the waste managent strategies for the achievement of SDGs: Trade-offs and synergies}

While addressing various sustainable development goals (SDGs), especially SDG 6 (clean water and sanitation), SDG 11 (sustainable cities and communities), SDG 12 (related with sustainable consumption and production) there exist synergy offering co-benefits and the enormous scope for sustainable waste management and resource recovery [72]. For example, the goal of reducing per capita global food waste at the retail and consumer levels and reducing food losses along its supply chains by halve (SDG 12.3) supports one of the key principles of 'waste reduction' under waste management. On the other hand, to inline waste management strategies with global SDGs, the government and line agencies could design the management strategies and program in a holistic approach to minimize impacts that adversely affect the prospects of achieving other developmental goals.

Waste management has become the livelihood of more than 15 million urban poor [4]. Diverting waste pickers into retrieving resources and co-creating city services, particularly in slum urban areas where no formal waste collection would otherwise happening is a good example of integrating poor within the circular economy [73], [74]). This could enhance their livelihood reducing poverty (SDGs $1.1,1.2$ ).

Reducing food loss and waste in its whole supply chain creates opportunities for others having food (SDGs 2.1 and 2.2) [75], which is also important from social justice perspective 
[75]. Reliable, safe, and affordable solid waste management services in the cities will help the city to keep safe, clean, and reducing environmental impact (SDG 11.6). This minimizes the possible pollution and contamination otherwise due to hazardous waste dumped in road sideways or burned in the open air or waste clogging the drains, which exacerbates floods, keeping water stagnant and contributing to many water-borne diseases (SDGs 3.2; 3.3 and 3.9).

Implementing an environmentally sound solid waste management system particularly for hazardous wastes (either chemical or biological hazardous wastes) will help to safeguard water quality by reducing pollution, eliminating dumping, and minimizing the release of hazardous materials (SDG 6.1). Handling hazardous chemicals and other waste in a systematic way helps to minimize their adverse impacts on human health and the environment (SDG 12.6) and ensure the conservation of terrestrial and inland freshwater ecosystems and their services (SDG 15.1) [76]. WtE strategies used in the management of MSW will help to increase the share of renewable energy in the energy mix (SDG 7.2). This will also prevent emissions of large amounts of greenhouse gases, which will help to combat climate change (SDG 13) [77]. The waste reduction principle of Reuse and Recycling created creates a significant potential for new job. Many small and medium-sized enterprises (SMEs) have been established within the waste management supply chain viz. second-hand shops, recycling centers enhancing the circularity (SDGs 8.2 and 8.6). Therefore, exploiting synergies and minimizing trade-offs across different policy and strategic areas within these cross-sector dimensions are important to make a successful MSW management system.

\section{ApPlication/NeEd of Circularity Measurement Framework For Urban Waste Management in CURITiba}

Curitiba is the capital city of the state of Paraná in Brazil with around 1.95 million inhabitants ${ }^{\mathrm{a}}$. The city is part of $\mathrm{C} 40$ initiative, which promotes fostering a cleaner and sustainable future through its climate action plan [78], [79]. At present, Iguaçu landfill (capacity: $2500 \mathrm{t} /$ day) receives the majority of MSW from the city of Curitiba and other municipalities in the greater metropolitan region [78]. The landfill also captures biogas and it has an installed capacity of $4.6 \mathrm{MW}$ gas turbine for power generation. Curitiba municipality generates 380.167 tonnes $(\mathrm{t})$ of household waste annually and the percentage of organic waste is around $37 \%[78]$.

A combination of assessment tools and optimization models discussed in section 3.1 and 3.2 should be implemented to improve its solid waste management from a circularity point of view in Curitiba. For example, LCA would be a great tool to explore the environmental impacts of different MSW options [16], [17] together with social lifecycle assessment (sLCA) [18]. Furthermore, multi-criteria optimization tools together with GIS spatial analysis would help achieve an optimal pathway towards the implementation of circular economy (see Table 1).

In order to compare Curitiba with other cities and urban areas from a circularity point of view, recycling rate (RR) [56] and waste hierarchy index (WHI) [51] should be used to evaluate the impacts of innovative technologies and solutions. The WHI was calculated for the 28 Members States of EU-28, and Iceland, Norway, and Switzerland, using Eurostat data [51]. The WHI helps to compare different urban areas and indentify the most successful scenarios.

\footnotetext{
${ }^{\text {a }}$ Brazilian Institute of Geography and Statistics https://www.ibge.gov.br/cidades-e-estados/pr/curitiba.html
} 
Game theory has been considered as a powerful tool to construct impactful institutional communication and interactions [53].There are also several examples that different cities and urban centers are trying to move toward a circular economy in waste management sector considering water-energy-food nexus approaches (see Section 3.4).

When it comes to institutions and stakeholders engaged in the management of solid waste in the city, Curitiba municipality coordinates with local and regional partners, including general people and international agencies [79]. It is important to explore the enablers and inhibitors of CE locally. Table 3 provides a few enabling and constraining factors in the promotion of circularity in the management of the MSW in the city of Cuitiba in Brazil. Training of the waste pickers in retrieving resources and co-creating city services will promote circularity whereas promoting SMEs to create the business of reuse (viz. secondhand shops) and recycling centers within the waste management supply chain will enable the circularity.

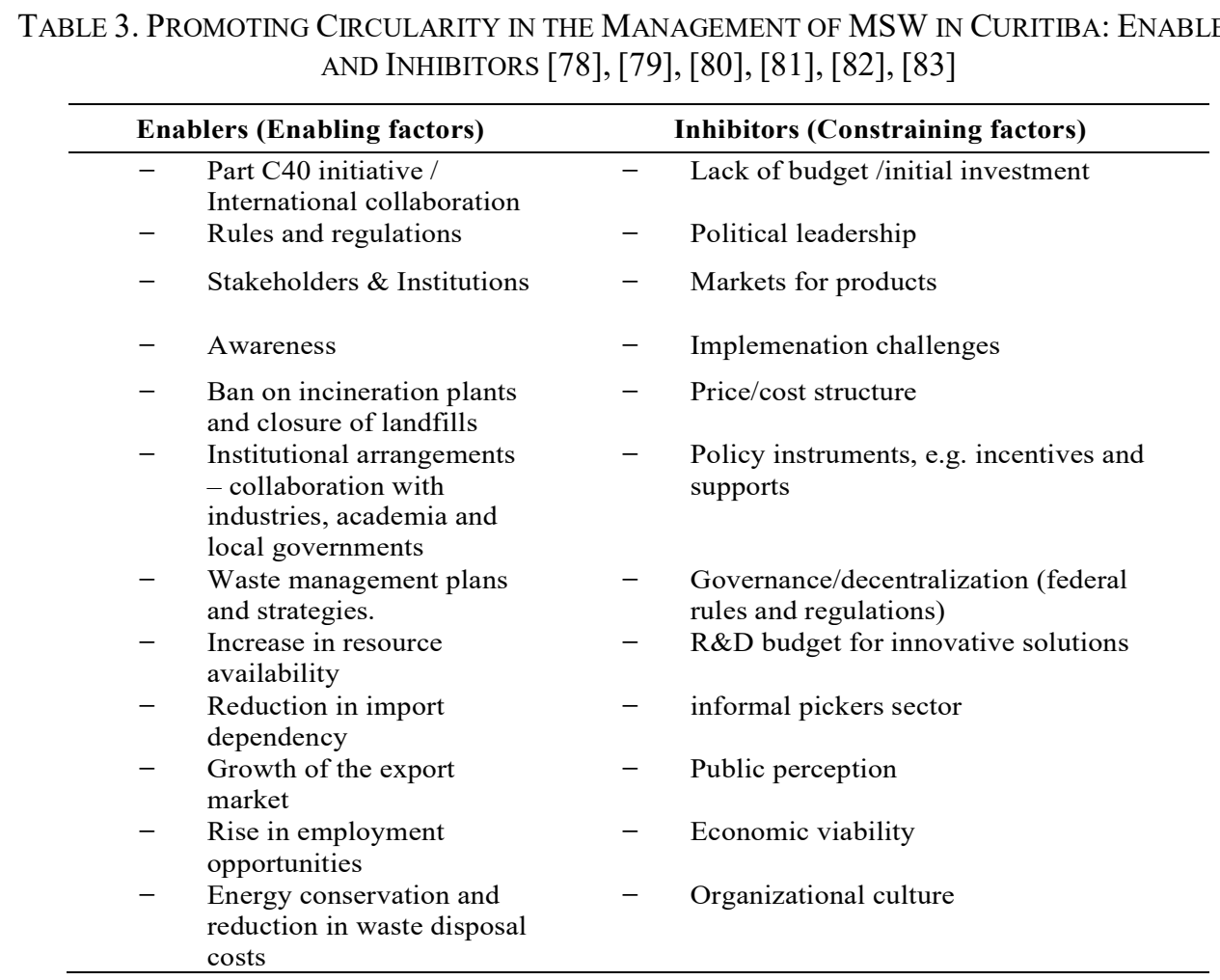

\section{Conclusions}

There are various tools, indicators, and metrics at different (micro, macro) levels for measuring circularity in the MSW sector. Life cycle assessment (LCA), material flow analysis (MFA), and spatial-optimization tools are important tools as they consider the entire supply chains, segregation/collection systems, waste management and conversion technologies, and resource recovery and associated environmental and economic benefits. These tools are used for comparing the worthiness of various waste management options and technological alternatives. Cities can be ranked according to the indicators identified in the study but there 
are challenges in obtaining necessary data since many cities do not have waste records.

The study proposes an integrated resource management systems that aims to increase the efficiency of natural resources utilization and reduce emissions and waste generation. For this purpose, the definition of systems boundaries, material/resource flows analysis, environmental accounting, together with innovative industrial symbiosis and circular economy is required to optimize the socioeconomic solution to improve the quality of the nexus in cities.

The key parameters affecting the CE widely vary depending on the problems being addressed and stakehoders' perspectives. In addition to core elements of CE, i.e. the direct circular handling of material and energy flows by closing loops, extending product life cycles, and increasing usage intensity; it is important to ensure that renewable, reusable, non-toxic resources are utilized as materials and energy in an efficient way. Analyzing the enablers is vital in promoting a circular economy allowing sustainability to be considered for business purposes and processes. Though the geo-spatial tools have major contributions in the effective management of MSW of cities, the most common inhibitors in the implementation of MSW management of cities is the lack of digital databases. The need for integrated holistic approaches covering all sysems is urgently required. The nexus should be evaluated considering positive and negative impacts. There is a great opportunity to include the interactions between MSW management options with energy, land use, climate change. Integrated MSW options would be able to balance potential trade-offs while delivering resource, nutrients, materials which will be later translated into social welfare and sustainable development.

Curitiba performs one of the best cities when it comes to the management of MSW waste. When it comes to institutions and stakeholders engaged in the management of MSW, the city of Curitiba coordinates with local and regional partners, including general people and international agencies. Ban on incineration plants, immediate closure of landfills, initiatives on energy and nutrient recovery from organic fraction of MSW, waste management plans and stratregies, and people's awareness are some of the enablers of CE. However, there are a few inhibitors which could make hindrances in transitioning towards CE. Training and co-creation of knowledge through research and development, engagement of SMEs in creating business of reuse (viz. second-hand shops) and recycling centers within the waste management supply chain will enable the circularity in the city.

\section{ACKNOWLEDGEMENT}

The research was financed by the Swedish Research Council FORMAS through project grant number 2017-00266.

\section{REFERENCES}

[1] Zhang D. Q., Tan S. K., Gersberg R. M. Municipal solid waste management in China: Status, problems and challenges. Journal of Environmental Management 2010:91(8):1623-1633. https://doi.org/10.1016/j.jenvman.2010.03.012

[2] Alfaia R. G. de S. M., Costa A. M., Campos J. C. Municipal solid waste in Brazil: A review. Waste Management \& Research 2017:35:1195-1209. https://doi.org/10.1177/0734242X17735375

[3] Ferronato N., Torretta V. Waste mismanagement in developing countries: A review of global issues. International Journal of Environmental Research and Public Health 2019:16:16061060. https://doi.org/10.3390/ijerph16061060

[4] World Bank. WHAT A WASTE 2.0 A Global Snapshot of Solid Waste Management to 2050. 2018. 
[5] Tsui T-H., Wong J. W. C. A critical review: emerging bioeconomy and waste-to-energy technologies for sustainable municipal solid waste management. Waste Disposal \& Sustainable Energy 2019:1:151-167. https://doi.org/10.1007/s42768-019-00013-Z

[6] Haghi E., Tehrani F. B. Techno-economic assessment of municipal solid waste incineration plant-case study of Tehran, Iran. First Sustain Dev Conf Eng Syst Energy Water Environ, 2015.

[7] Liao C-H., Chiu A. S. F. Evaluate municipal solid waste management problems using hierarchical framework. Procedia - Social and Behavioral Sciences 2011:25:353-362. https://doi.org/10.1016/j.sbspro.2011.10.554

[8] Taleb M. A., Al Farooque O. Towards a circular economy for sustainable development: An application of full cost accounting to municipal waste recyclables. Journal of Cleaner Production 2021:280:124047. https://doi.org/10.1016/j.jclepro.2020.124047

[9] Fernández-Delgado M., Amo-Mateos E. del, Lucas S., García-Cubero M. T., Coca M. Recovery of organic carbon from municipal mixed waste compost for the production of fertilizers. Journal of Cleaner Production 2020:265:121805. https://doi.org/10.1016/j.jclepro.2020.121805

[10] Nasir IM, Ghazi TIM, Omar R. Production of biogas from solid organic wastes through anaerobic digestion: A review. Applied Microbiology and Biotechnology 2012:95:321-329. https://doi.org/10.1007/s00253-012-4152-7

[11] Scarlat N., Dallemand J. F., Monforti-Ferrario F., Nita V. The role of biomass and bioenergy in a future bioeconomy: Policies and facts. Environmental Development 2015:15:3-34. https://doi.org/10.1016/j.envdev.2015.03.006

[12] Sherwood J. The significance of biomass in a circular economy. Bioresource Technology 2020:300:122755. https://doi.org/10.1016/j.biortech.2020.122755

[13] Nizami A. S., Rehan M., Waqas M., Naqvi M., Ouda O. K. M., Shahzad K., et al. Waste biorefineries: Enabling circular economies in developing countries. Bioresource Technology 2017:241:1101-1117. https://doi.org/10.1016/j.biortech.2017.05.097

[14] Paes L. A. B., Bezerra B. S., Deus R. M., Jugend D., Battistelle R. A. G. Organic solid waste management in a circular economy perspective - A systematic review and SWOT analysis. Journal of Cleaner Production 2019:239:118086. https://doi.org/10.1016/j.jclepro.2019.118086

[15] de Sadeleer I., Brattebø H., Callewaert P. Waste prevention, energy recovery or recycling - Directions for household food waste management in light of circular economy policy. Resources, Conservation and Recycling 2020:160:104908. https://doi.org/10.1016/j.resconrec.2020.104908

[16] Ayodele T. R., Ogunjuyigbe A. S. O., Alao M. A. Life cycle assessment of waste-to-energy (WtE) technologies for electricity generation using municipal solid waste in Nigeria. Applied Energy 2017:201:200-218. https://doi.org/10.1016/j.apenergy.2017.05.097

[17] Jeswani H. K., Azapagic A. Assessing the environmental sustainability of energy recovery from municipal solid waste in the UK. Waste Management 2016:50:346-363. https://doi.org/10.1016/j.wasman.2016.02.010

[18] Alidoosti Z., Ahmad S., Govindan K., Pishvaee M. S., Mostafaeipour A., Hossain A. K. Social sustainability of treatment technologies for bioenergy generation from the municipal solid waste using best worst method. Journal of Cleaner Production 2021:288:125592. https://doi.org/10.1016/j.jclepro.2020.125592

[19] Sharma B. K., Chandel M. K. Life cycle cost analysis of municipal solid waste management scenarios for Mumbai, India. Waste Management 2021:124:293-302. https://doi.org/10.1016/j.wasman.2021.02.002

[20] Sadhukhan J., Martinez-Hernandez E. Material flow and sustainability analyses of biorefining of municipal solid waste. Bioresource Technology 2017:243:135-146. https://doi.org/10.1016/j.biortech.2017.06.078

[21] Babalola M. A. A Multi-Criteria Decision Analysis of Waste Treatment Options for Food and Biodegradable Waste Management in Japan. Environments 2015:2(4):471-488. https://doi.org/10.3390/environments2040471

[22] Qazi W. A., Abushammala M. F. M., Azam M. H. Multi-criteria decision analysis of waste-to-energy technologies for municipal solid waste management in Sultanate of Oman. Waste Management \& Research 2018:36(7):594-605. https://doi.org/10.1177/0734242X18777800

[23] Kazuva E., Zhang J. Analyzing Municipal Solid Waste Treatment Scenarios in Rapidly Urbanizing Cities in Developing Countries: The Case of Dar es Salaam, Tanzania. International Journal of Environmental Research and Public Health 2019:16(11):2035. https://doi.org/10.3390/ijerph16112035

[24] Abdallah M., Abu Talib M., Feroz S., Nasir Q., Abdalla H., Mahfood B. Artificial intelligence applications in solid waste management: A systematic research review. Waste Management 2020:109:231-246. https://doi.org/10.1016/j.wasman.2020.04.057

[25] Kalmykova Y., Sadagopan M., Rosado L. Circular economy - From review of theories and practices to development of implementation tools. Resources, Conservation and Recycling 2018:135:190-201. https://doi.org/10.1016/j.resconrec.2017.10.034

[26] Gallego-Schmid A., Chen H. M., Sharmina M., Mendoza J. M. F. Links between circular economy and climate change mitigation in the built environment. Journal of Cleaner Production 2020:260:121115. https://doi.org/10.1016/i.jclepro.2020.121115 
[27] Malinauskaite J., Jouhara H., Czajczyńska D., Stanchev P., Katsou E., Rostkowski P., et al. Municipal solid waste management and waste-to-energy in the context of a circular economy and energy recycling in Europe. Energy 2017:141:2013-2044. https://doi.org/10.1016/j.energy.2017.11.128

[28] Kitchenham B., Charters S. Guidelines for performing Systematic Literature Reviews in Software Engineering. Keele University and Durham University Joint Report, 2007.

[29] Esposito B., Sessa M. R., Sica D., Malandrino O. Towards Circular Economy in the Agri-Food Sector. A Systematic Literature Review. Sustainability 2020:12:7401. https://doi.org/10.3390/su12187401

[30] Hrabec D., Kůdela J., Šomplák R., Nevrlý V., Popela P. Circular economy implementation in waste management network design problem: a case study. Central European Journal of Operations Research 2020:28:1441-1458. https://doi.org/10.1007/s10100-019-00626-Z

[31] Rathore P., Sarmah S. P. Economic, environmental and social optimization of solid waste management in the context of circular economy. Computers \& Industrial Engineering 2020:145:106510. https://doi.org/10.1016/j.cie.2020.106510

[32] Loizia P., Neofytou N., Zorpas A. A. The concept of circular economy strategy in food waste management for the optimization of energy production through anaerobic digestion. Environmental Science and Pollution Research 2019:26:14766-14773. https://doi.org/10.1007/s11356-018-3519-4

[33] Molina-Sánchez E., Leyva-Díaz J. C., Cortés-García F. J., Molina-Moreno V. Proposal of Sustainability Indicators for the Waste Management from the Paper Industry within the Circular Economy Model. Water 2018:10(8):10081014. https://doi.org/10.3390/w10081014

[34] Fetanat A., Tayebi M., Shafipour G. Management of waste electrical and electronic equipment based on circular economy strategies: navigating a sustainability transition toward waste management sector. Clean Technologies and Environmental Policy 2021:23:343-369. https://doi.org/10.1007/s10098-020-02006-7

[35] Tomić T., Schneider D. R. Circular economy in waste management - Socio-economic effect of changes in waste management system structure. Journal of Environmentak Management 2020:267:110564. https://doi.org/10.1016/j.jenvman.2020.110564

[36] Berechet M., Mirel I., Staniloiu C., Fischer K. Carbon footprint of waste management in romania in the context of circular economy. Environmental Engineering and Management Journal 2019:18(6):1289-1295. https://doi.org/10.30638/eemj.2019.123

[37] Kara C., Doratli N. Application of GIS/AHP in siting sanitary landfill: A case study in Northern Cyprus. Waste Management \& Research 2012:30(9):966-980. https://doi.org/10.1177/0734242X12453975

[38] Ersoy H., Bulut F. Spatial and multi-criteria decision analysis-based methodology for landfill site selection in growing urban regions. Waste Management \& Research 2009:27(5):489-500. https://doi.org/10.1177/0734242X08098430

[39] Mallick J. Municipal Solid Waste Landfill Site Selection Based on Fuzzy-AHP and Geoinformation Techniques in Asir Region Saudi Arabia. Sustainability 2021:13(3):1538. https://doi.org/10.3390/su13031538

[40] Amal L., Son L. H., Chabchoub H., Lahiani H. Analysis of municipal solid waste collection using GIS and multicriteria decision aid. Applied Geomatics 2020:12:193-208. https://doi.org/10.1007/s12518-019-00291-6

[41] Nguyen-Trong K., Nguyen-Thi-Ngoc A., Nguyen-Ngoc D., Dinh-Thi-Hai V. Optimization of municipal solid waste transportation by integrating GIS analysis, equation-based, and agent-based model. Waste Management 2017:59:1422. https://doi.org/10.1016/j.wasman.2016.10.048

[42] Alkaradaghi K., Ali S. S., Al-Ansari N., Laue J., Chabuk A. Landfill Site Selection Using MCDM Methods and GIS in the Sulaimaniyah Governorate, Iraq. Sustainability 2019:11(17):4530. https://doi.org/10.3390/su11174530

[43] Zelenović Vasiljević T., Srdjević Z., Bajčetić R., Vojinović Miloradov M. GIS and the analytic hierarchy process for regional landfill site selection in transitional countries: A case study from Serbia. Environmental Management 2012:49:445-458. https://doi.org/10.1007/s00267-011-9792-3

[44] Palafox-Alcantar P. G., Hunt D. V. L., Rogers C. D. F. A Hybrid Methodology to Study Stakeholder Cooperation in Circular Economy Waste Management of Cities. Energies 2020:13(7):13071845.

https://doi.org/10.3390/en13071845

[45] Sharma M., Joshi S., Kumar A. Assessing enablers of e-waste management in circular economy using DEMATEL method: An Indian perspective. Environmental Science and Pollution Research 2020:27:13325-13338. https://doi.org/10.1007/s11356-020-07765-w

[46] Symeonides D., Loizia P., Zorpas A. A. Tire waste management system in Cyprus in the framework of circular economy strategy. Environmental Science and Pollution Research 2019:26:35445-35460.

https://doi.org/10.1007/s11356-019-05131-z

[47] Salguero-Puerta L., Leyva-Díaz J. C., Cortés-García F. J., Molina-Moreno V. Sustainability Indicators Concerning Waste Management for Implementation of the Circular Economy Model on the University of Lome (Togo) Campus. Environmental Research and Public Health 2019:16(12):2234. https://doi.org/10.3390/ijerph16122234 
[48] Luttenberger L. R. Waste management challenges in transition to circular economy - Case of Croatia. Journal of Cleaner Production 2020:256:120495. https://doi.org/https://doi.org/10.1016/j.jclepro.2020.120495

[49] Tsai F. M., Bui T-D., Tseng M-L., Lim M. K., Hu J. Municipal solid waste management in a circular economy: A data-driven bibliometric analysis. Journal of Cleaner Production 2020:275:124132. https://doi.org/https://doi.org/10.1016/j.jclepro.2020.124132

[50] Laso J. et al. Waste management under a life cycle approach as a tool for a circular economy in the canned anchovy industry. Waste Management \& Research 2016:34(8):724-733. https://doi.org/10.1177/0734242X16652957

[51] Pires A., Martinho G. Waste hierarchy index for circular economy in waste management. Waste Management 2019:95:298-305. https://doi.org/10.1016/j.wasman.2019.06.014

[52] Mahpour A. Prioritizing barriers to adopt circular economy in construction and demolition waste management. Resources, Conservation and Recycling 2018:134:216-227. https://doi.org/10.1016/j.resconrec.2018.01.026

[53] Palafox-Alcantar P. G., Hunt D. V. L., Rogers C. D. F. The complementary use of game theory for the circular economy: A review of waste management decision-making methods in civil engineering. Waste Management 2020:102:598-612. https://doi.org/10.1016/j.wasman.2019.11.014

[54] Bartolacci F., Del Gobbo R., Paolini A., Soverchia M. Waste management companies towards circular economy: what impacts on production costs? Environmental Engineering and Management Journal 2017:16(8):1789-1796. http://dx.doi.org/10.30638/eemj.2017.195

[55] Parajuly K., Wenzel H. Product Family Approach in E-Waste Management: A Conceptual Framework for Circular Economy. Sustainability 2017:9(5):9050768. https://doi.org/10.3390/su9050768

[56] Haupt M., Vadenbo C., Hellweg S. Do We Have the Right Performance Indicators for the Circular Economy?: Insight into the Swiss Waste Management System. Journal of Industrial Ecology 2017:21(3):615-627. https://doi.org/10.1111/jiec.12506

[57] Schneider P., Anh L. H., Wagner J., Reichenbach J., Hebner A. Solid Waste Management in Ho Chi Minh City, Vietnam: Moving towards a Circular Economy? Sustainability 2017:9(2):9020286. https://doi.org/10.3390/su9020286

[58] Fedotkina O., Gorbashko E., Vatolkina N. Circular Economy in Russia: Drivers and Barriers for Waste Management Development. Sustainability 2019:11(20):11205837. https://doi.org/10.3390/su11205837

[59] Ribić B., Voća N., Ilakovac B. Concept of sustainable waste management in the city of Zagreb: Towards the implementation of circular economy approach. $J$ Air Waste Manage Assoc 2017:67(2):241-259. https://doi.org/10.1080/10962247.2016.1229700

[60] Smol M., Duda J., Czaplicka-Kotas A., Szołdrowska D. Transformation towards Circular Economy (CE) in Municipal Waste Management System: Model Solutions for Poland. Sustainability 2020:12(11):12114561. https://doi.org/10.3390/su12114561

[61] Fatimah Y. A., Govindan K., Murniningsih R., Setiawan A. Industry 4.0 based sustainable circular economy approach for smart waste management system to achieve sustainable development goals: A case study of Indonesia. Journal of Cleaner Production 2020:269:122263. https://doi.org/10.1016/j.jclepro.2020.122263

[62] Howells M., Hermann S., Welsch M., Bazilian M., Segerström R., Alfstad T., et al. Integrated analysis of climate change, land-use, energy and water strategies. Nature Climate Change 2013:3:621-626. https://doi.org/10.1038/nclimate1789

[63] Bazilian M., Rogner H., Howells M., Hermann S., Arent D., Gielen D., et al. Considering the energy, water and food nexus: Towards an integrated modelling approach. Energy Policy 2011:39(12):7896-7906. https://doi.org/10.1016/j.enpol.2011.09.039

[64] Lehmann S. Conceptualizing the Urban Nexus Framework for a Circular Economy: Linking Energy, Water, Food, and Waste (EWFW) in Southeast-Asian cities. Renewable Strategies for Cities and Regions 2018:371-398. https://doi.org/10.1016/B978-0-08-102074-6.00032-2

[65] Meng F., Liu G., Liang S., Su M., Yang Z. Critical review of the energy-water-carbon nexus in cities. Energy 2019:171:1017-1032. https://doi.org/10.1016/j.energy.2019.01.048

[66] Mo W., Zhang Q. Energy-nutrients-water nexus: Integrated resource recovery in municipal wastewater treatment plants. Journal of Environmental Management 2013:127:255-267. https://doi.org/10.1016/j.jenvman.2013.05.007

[67] Xu M., Fan B., Zhang Y., Li A., Li Y., Lv M., et al. Effects of resource-oriented waste management on optimizing water-food-energy nexus in rural China: A material and energy flow analysis. Journal of Cleaner Production 2020:276:124259. https://doi.org/10.1016/j.jclepro.2020.124259

[68] Artioli F., Acuto M., Mcarthur J., McArthur J. The water-energy-food nexus: An integration agenda and implications for urban governance. Political Geography 2017:61:215-223. https://doi.org/10.1016/j.polgeo.2017.08.009

[69] Caputo S., Schoen V., Specht K., Grard B., Blythe C., Cohen N., et al. Applying the food-energy-water nexus approach to urban agriculture: From FEW to FEWP (Food-Energy-Water-People). Urban Forestry \& Urban Greening 2021:58:126934. https://doi.org/10.1016/j.ufug.2020.126934 
[70] Fouladi J., AlNouss A., Al-Ansari T. Sustainable energy-water-food nexus integration and optimisation in ecoindustrial parks. Computers \& Chemical Engineering 2021:146:107229. https://doi.org/10.1016/j.compchemeng.2021.107229

[71] Friedrich J., Poganietz W. R., Lehn H. Life-cycle assessment of system alternatives for the Water-Energy-Waste Nexus in the urban building stock. Resources, Conservation and Recycling 2020:158:104808. https://doi.org/10.1016/j.resconrec.2020.104808

[72] Velenturf A. P. M., Purnell P. Resource Recovery from Waste: Restoring the Balance between Resource Scarcity and Waste Overload. Sustainability 2017:9(9):1603. https://doi.org/10.3390/su9091603

[73] Gutberlet J, Carenzo S, Kain J-H, Mantovani Martiniano de Azevedo A. Waste Picker Organizations and Their Contribution to the Circular Economy: Two Case Studies from a Global South Perspective. Resources 2017:6(4):52. https://doi.org/10.3390/resources6040052

[74] Gutberlet J. Grassroots waste picker organizations addressing the UN sustainable development goals. World Development 2021:138:105195. https://doi.org/10.1016/j.worlddev.2020.105195

[75] Thapa Karki S., Bennett A. C. T., Mishra J. L. Reducing food waste and food insecurity in the UK: The architecture of surplus food distribution supply chain in addressing the sustainable development goals (Goal 2 and Goal 12.3GG) at a city level. Industrial Marketing Management 2020:93:563-577. https://doi.org/10.1016/j.indmarman.2020.09.019

[76] Hannan M. A., Hossain Lipu M. S., Akhtar M., Begum R. A., AlMamun M. A., Hussain A., et al. Solid waste collection optimization objectives, constraints, modeling approaches, and their challenges toward achieving sustainable development goals. Journal of Cleaner Production 2020:277:123557. https://doi.org/10.1016/j.jclepro.2020.123557

[77] Rodić L., Wilson D. Resolving Governance Issues to Achieve Priority Sustainable Development Goals Related to Solid Waste Management in Developing Countries. Sustainability 2017:9(3):404. https://doi.org/10.3390/su9030404

[78] Remy F. Potential for the anaerobic digestion of municipal solid waste ( MSW ) in the city of Curitiba, Brazil 2018.

[79] International Finance Corporation. Curitiba Solid Waste Management 2015:1-23.

[80] Björklund S., Öhman N. Biogas opportunities in Curitiba: Analysis of business potential for biogas production from municipal solid waste. KTH Royal Institute of Technology, 2017.

[81] CCAC. Climate and Clean Air Coalition Municipal Solid Waste Initiative Solid Waste Management City Profile 2015:997:1-13.

[82] Luiz C, Ceccon NP. Institutional Arrangement of the Intermunicipal Consortium of the Metropolitan Region of Curitiba for Management of Municipal Solid Waste. Urban Public Econ Rev 2011:46-73.

[83] da Silva C. L. Proposal of a dynamic model to evaluate public policies for the circular economy: Scenarios applied to the municipality of Curitiba. Waste Management 2018:78:456-466. https://doi.org/10.1016/j.wasman.2018.06.007 